\title{
RESEARCH INTO THE STATUS OF SPECIAL ADMINISTRATIVE REGIONS IN CHINA
}

\author{
NINA SYMANIUK, \\ Ural Federal University (Yekaterinburg, Russia) \\ OLGA TOMBERG, \\ Ural Federal University (Yekaterinburg, Russia) \\ XIAOWEN ZHANG, \\ Shanghai University (Shanghai, China)
}

https://doi.org/10.21684/2412-2343-2021-8-4-62-75

This article analyzes the legal status of special administrative regions in China. This type of territorial unit occupies a special place and has a specific legal status, which is especially noticeable in relations with the central authorities. The authors focus on the historical prerequisites for the formation of such a legal status and analyze the current situation. A special feature of this study is the research methodology, since a comprehensive analysis requires the use of a mixed research method. The conclusions reached by the authors can be used to formulate a new form of government.

Keywords: special administrative regions; government; China; executive power; legislative power; judiciary.

Recommended citation: Nina Symaniuk et al., Research into the Status of Special Administrative Regions in China, 8(4) BRICS Law Journal 62-75 (2021).

\section{Table of Contents}

Introduction

1. Research Methods

2. Research Results 


\section{Immigration and Citizenship \\ 4. Formation of Executive Power in Hong Kong \\ 5. Formation of Legislative Power in Hong Kong \\ 6. Advantages and Necessity of Establishing the Status of a Special Administrative Region \\ 7. Problems Revealed in the Process of Development Conclusion}

\section{Introduction}

Located in the southeast corner of the People's Republic of China,' Hong Kong was a sparsely populated fishing village under the Qing Dynasty, when it was ceded to the British Government in 1843 because of the First Opium War. ${ }^{2}$ After the Second Opium War, ${ }^{3}$ under 99-year lease agreement, the adjoining territories were added. Except for the Japanese occupation during World War II, it remained under British control until 1997 when it was returned to the People's Republic of China within a“One Country Two Systems" framework (“国两制” in Chinese). Since then, it maintains a higher degree of autonomy in accordance with the Basic Law of Hong Kong Special Administrative Region (HKSAR). ${ }^{4}$

Being a unitary country itself, China has a total of 34 provincial-level administrative regions, including 23 provinces, 5 autonomous regions, 4 municipalities, and 2 special administrative regions. However, the "One Country Two Systems" framework makes Hong Kong and Macau the only two capitalist regions, that results in a different type of central-local relationship. On the one hand, the effectiveness of this policy can be proved by more than 20 years of stable governance. On the other, recent social unrest and disturbances reveal growing problems. According to Mee Kam Ng, HKSAR continues to be a non-democratic, administrative city administrated by an "executive-led" government. Globalization led to introducing new changes in a mode of governance, economic and political restructuring. This can be seen in a shift in policy-making and implementation from top-down government-led modes towards networks of cross-sectoral partnerships, which are characterized by shared power. The developing countries go through a three-stage process: a period of state-led growth with a strong state and a weak civil society, followed by a transitional period

\footnotetext{
Constitution of the People's Republic of China (Sep. 2, 2021), available at http://www.npc.gov.cn/ englishnpc/constitution2019/201911/1f65146fb6104dd3a2793875d19b5b29.shtml.

2 Michael Faure \& Ton Hartlief, Economic Analysis in The Impact of Social Security Law on Tort Law 222 (Ulrich Magnus ed., 2003).

Id. at 253-255.

4 Gerard A. Postiglione, Education and Social Change in China: Inequality in a Market Economy 97 (2006).
} 
when the civil society becomes more powerful and comes into conflict with the state. Finally, in the third period two outcomes are possible: paralyzed development caused by state domination or excessively strong civil society; or sustainable development that results from a stable balance of power between the state and civil society.

With different opinions and discussions on this topic being taken into consideration, this paper aims to give a comprehensive study of this innovative type of governance and introduce the main content of this policy, its historical background, peculiar features, current power types and situation in HKSAR. Policy advantages and challenges will be analyzed on the basis of mixed methodology. The final part of the article discusses lessons drawn from the application of the model and its necessity.

\section{Research Methods}

The research is based on a combination of methods: analysis and synthesis, historical and legal methods, Mix Methods Research. The use of general scientific methods of analysis and synthesis allow to identify individual elements of the state complex structure, i.e. a combination of unitary state features and federal characteristics. Besides, the analysis method is used to identify and describe such concepts as factors affecting the content of the state structure and their effects. With the help of the historical and legal method, an extensive retrospective analysis of foreign practice in the field of legal regulation of the state structure will be carried out within the study framework. It will allow to identify the historical necessity and its predetermination, describe the prerequisites for current trends in this area, outline the dynamics of the evolution of the institute and its main directions. The application of these methods has a specific character because the scientific issues under consideration are interdisciplinary.

Mix Methods Research is a set of quantitative and qualitative methods of data collection, which allows to combine formalized statistical methods and techniques of qualitative interpretive analysis to form a semantic field that characterizes the object under study. The most complete definition of the strategy of mixing methods is given by J.W. Creswell:

In the strategies of mixing methods, the researcher collects and analyzes both qualitative and quantitative data based on the research question; one mixes (integrates or combines) them in parallel or sequentially, while giving greater importance to one of them or both; uses these procedures in one study or in multiple phases of the research program; considers these procedures within the framework of the chosen philosophical or theoretical approach; develops a unique research design with several methods. ${ }^{5}$

\footnotetext{
John W. Creswell \& Vicki L. Plano Clark, Designing and Conducting Mixed Methods Research 95-108 $\left(2^{\text {nd }}\right.$ ed. 2011).
} 
The use of a mixed research method will allow us to develop scenarios for emulating positive Chinese experience.

\section{Research Results}

The People's Republic of China (PRC) is a socialist state in which, according to Article 2 of the Constitution of the People's Republic of China, all power in the Republic belongs to the people. The leadership of the Communist Party of China ${ }^{6}$ acts as a certain feature of socialism with Chinese characteristics. No organization or group can violate this system.

There are two levels of government in the People's Republic of China: central and municipal. The first level is the National People's Congress (NPC), which is the highest state authority of the People's Republic of China and is formed through democratic elections, the second is 23 provinces, 5 autonomous regions, 4 municipalities that are directly subordinate to the central government, 2 special administrative regions. It is worth noting that it is the NPC that approves the formation of provinces, autonomous regions and municipalities, and also decides on the creation of special administrative regions. Further, in accordance with Article 30 of the Constitution of the People's Republic of China, provinces and autonomous regions are divided into autonomous prefectures (districts), counties, autonomous counties and cities. Counties and autonomous counties, in turn, include townships, national towns and cities. Municipalities and other large cities are divided into districts and counties, autonomous prefectures (districts) - into counties, autonomous counties and cities. All autonomous regions, autonomous prefectures and autonomous counties act as autonomous national regions.

An important fact is the fact enshrined in Article 134 of the Constitution of China, which establishes that citizens of all nationalities have the right to use their native oral and written language in court hearings. Thus, the people's courts and the People's Procuracy bodies must provide translation to any party to the court hearing, if she is not familiar with the language used in these proceedings.

Speaking about the principle of separation of powers between central and municipal authorities, it should be clarified that it is based on providing a"full scope for thoughts and creativity" of local authorities, ensuring a decent standard of living for people under the unified leadership of the central authorities. In addition, the center controls the legislative power of local assemblies of people's representatives. Nevertheless, in accordance with Article 100 of the Constitution of the People's Republic of China, the above-mentioned provincial and municipal bodies and their standing committees may adopt local resolutions (directives) that should not

6 Michael Firth et al., Friend or Foe? The Role of State and Mutual Fund Ownership in the Split Share Structure Reform in China, 45(3) J. Fin. Quant. Anal. 685 (2010). 
contradict the Constitution, National People's Congress laws, as well as administrative rules and instructions approved by the State Council of the People's Republic of China. Further, local public authorities must report the adopted directives to the Standing Committee of the National People's Congress for registration. Moreover, the People's Congress of a city divided into districts and its Standing Committee may adopt resolutions that should not contradict the Constitution, laws, administrative regulations and local directives of the province or autonomous prefecture (district) and must be submitted for approval by the Standing Committee of the People's Assembly of the Province or Autonomous District. It is worth noting that the Standing Committee of the National People's Congress has a right to cancel local resolutions and decisions of the authorities of provinces, autonomous regions and municipalities directly subordinate to the central government if these normative legal acts (NPA) contradict the Constitution, laws, or administrative rules or instructions. In addition to adopting and issuing resolutions, Local Assemblies of People's Representatives consider and adopt plans for the economic and cultural development of their territories, development of public services. Local assemblies of people's representatives at the county level and above should consider and adopt socio-economic development plans and budgets of their administrative districts, check and approve reports on their implementation. It is noteworthy that these authorities, acting at their own level, elect and have the authority to recall governors, vice-governors, mayors, their deputies, heads and their deputies of counties, districts, towns, etc.

The State Council of the People's Republic of China as the highest executive power of the Republic creates an audit body to monitor the income and expenses of all departments and local governments accountable to it at different levels, income and expenses of all financial and monetary organizations, all enterprises and institutions in the country.

In accordance with Article 105 of the Constitution of the People's Republic of China, Local People's Governments of various levels are the executive bodies of local government organizations, as well as local government organizations of the appropriate level under the unified leadership of the State Council of the People's Republic of China and are subordinate to it. Local people's governments are engaged in administrative work in the field of economy, education, culture, health, physical culture, urban and rural development, finance, public security. They adopt decrees and resolutions, appoint or remove officials, conduct their training, evaluate their work, and eventually encourage or punish them. The urban and rural population creates committees at the place of residence, which are mass organizations of selfgovernment. Such committees create committees on public safety, health and other issues in order to manage civil affairs and public services in their districts, regulate civil disputes, and maintain public order. In addition, city and village committees serve as a kind of conductors of public opinions and demands of the population, making proposals to the people's government. 
Regional autonomy is practiced in areas where representatives of national minorities live in strong, concentrated communities. In these areas, self-government bodies are being created to exercise the power of autonomy and to enforce laws and state policy. It is noteworthy that national autonomous regions have the power to manage their finances. Thus, in accordance with Article 117 of the Constitution of the People's Republic of China, the income received by them within the framework of the state financial system is managed and used by the self-government bodies of these districts at their own discretion. In addition, the self-governing bodies of the national autonomous regions independently organize the management of the district economic development, guided by state plans. In addition, the state is obliged to consider their interests while building enterprises and developing natural resources in these areas. Among other things, autonomous regions, if necessary, have the right to organize local public security forces to maintain public order. In general, the self-governing bodies of national autonomies independently manage education, science, culture, health care in their districts, protect cultural heritage and hold events aimed at the dynamic development of their cultures.

Particular focus of the paper is on the internal structure and procedure for the formation of authorities of Special Administrative Regions (SAR), in particular Hong Kong and Macau. According to Article 31 of the Constitution of the People's Republic of China, the State may, if necessary, create special administrative regions. The system created in a special administrative region must be prescribed by a law adopted by the National People's Congress.

The concept of SAR was included in the Constitution of 1982 with a hope for the return of Taiwan, Hong Kong and Macau under the sovereignty of Beijing. In July 1997, Hong Kong was handed over to the outgoing British colonial administration, and in December 1999, Macau was returned to Portugal. The administration of these two special administrative regions is covered by Beijing's "One Country, Two Systems" concept, which guarantees that within 50 years they will be able to maintain their former economic and political systems. Thus, Hong Kong will be able to maintain its capitalist economic system under the leadership of a chief representative (appointed by Beijing) and partially elected legislature.

Special administrative regions (as municipal units) have the highest degree of autonomy in China. Despite the relative autonomy that the Central People's Government grants to special administrative regions, the National People's Congress can still write laws for special administrative regions unilaterally and secretly. These laws are not published until they are adopted.

In accordance with the principle of "One Country, Two Systems," the two special administrative regions continue to have their own governments, multiparty legislatures, legal systems, police, monetary systems, separate customs territories, immigration policy, national sports teams, official languages, postal systems, academic and educational systems, as well as significant competence in foreign relations other than or independent of the PRC. 
Each of the two special administrative regions - Hong Kong and Macau - has a codified constitution, which is called the Basic Law. The law grants the regions a high degree of autonomy, a separate political system and a capitalist economy in accordance with the principle of "one country, two systems" proposed by Deng Xiaoping.

Currently, Hong Kong and Macau are responsible for all matters except diplomatic relations and national defense. Consequently, the National People's Congress authorizes the SAR to exercise a high degree of autonomy and use executive, legislative and independent judicial power, and each has its own courts of last resort.

Special administrative regions have the right to conclude a wide range of agreements with other countries and territories: mutual visa cancellation, mutual legal assistance, air transportation, extradition (a form of international cooperation between States in combating crimes, consisting in the arrest and transfer by one State to another of persons suspected or accused of committing a crime (for trial), or persons already convicted by the judicial authorities of another State), double taxation processing and others, without the participation of the Chinese government.

However, in some diplomatic negotiations involving special administrative regions, the relevant SAR may send officials to the Chinese delegation (for example, when the former Director of the Hong Kong Department of Health, Margaret Chan, became Director General of the World Health Organization (WHO), she worked as a delegate from the People's Republic of China to WHO).

The Hong Kong Government has established Hong Kong Economic and Trade Offices (HKETOS) that are Hong Kong's trade representative offices outside the Territory. There are 12 offices outside the Greater China region and eight in the Greater China region (one in Taiwan, four offices and three liaison groups in mainland China.

Both SARs have garrisons of the People's Liberation Army (the regular armed forces of the People's Republic of China (PRC) and the ruling political Party of the People's Republic of China, the Communist Party of China (CPC). The Chinese authorities have stated that the PLA will not be allowed to interfere in the local affairs of Hong Kong and Macau. The PLA does not participate in the management of the SAR, but the latter can ask for their civil-military participation during emergencies, such as natural disasters, since defense is the responsibility of the PRC government.

\section{Immigration and Citizenship}

The authorities of Hong Kong and Macau independently issue passports to their permanent residents who are also citizens of China (PRC). Permanent residents of SAR who are not Chinese citizens (including stateless persons) are not eligible for SAR passports. Persons who are not Chinese citizens must obtain passports from foreign?

Percy R. Luney, Jr., Traditions and Foreign Influences: Systems of Law in China an, 52(2) L. Contemp. Probl. 129 (1989). 
diplomatic missions representing their countries of citizenship. For stateless persons, each SAR can issue its own identity cards, for example, an identity document, instead of national passport for some persons. Chinese citizens who are not permanent residents of the two SARs are also not eligible for SAR passports.

There is no article in the Constitution of the People's Republic of China establishing the State or official language. That is, legally, no language in the country is the state language, it has definite political grounds. In fact, Chinese is a main means of communication throughout the country. It is used for television and radio broadcasting; it is the language of many educational institutions. This gives reason to believe that Chinese is the de facto state language of the People's Republic of China and the official language of the country's administrative structures. The Constitution uses the definition of "commonly used," but not official. The legislator does not want to use the phrase "state language" because of its obvious national content and seeks to formalize the status of the Chinese language as much as possible so that it is not perceived as a factor of cultural dominance of the Han ethnic group over other peoples of the country. It is closely related to the objectives of China's national policy: according to Article 4 of the Constitution of the People's Republic of China all peoples have the right to use and develop their native language, both written and oral, and to preserve or improve their folk customs and traditions.

According to Article 9 of the Basic Law of Macau, Portuguese can also be used as an official language (together with Chinese) by its executive, legislative and judicial bodies. According to Article 9 of the Basic Law of Hong Kong English can also be used as the official language (together with Chinese) in all Hong Kong authorities. According to Article 19 of the Constitution of China, the State ensures the dissemination of the generally accepted Chinese language throughout the territory.

Articles 2 and 3 of the Law of the People's Republic of China "On the Commonly Used Language and Writing" repeat the content of the norms on the status of the language, according to Article 19 of the Constitution of the People's Republic of China but expand it somewhat. The NPA adds that "the State promotes the spread of unified writing, which means modern simplified hieroglyphs, the list of which is approved by the State Council of the People's Republic of China." Article 4 of this law obliges local authorities to take measures to spread Putonghua in the regions (Article 4 illustrates an interference of the authorities in the development of languages of ethnic minorities and the oppression of local dialects). Article 16 establishes a scope of possible usage of local dialects. They can be used by: employees of public services to perform their duties; television and radio broadcasting, if such a measure is approved by the Minister of Television and Radio Broadcasting or the regional Department for Television and Radio Broadcasting; in the works of theatrical and cinema art; in book publishing, education and scientific research, if necessary.

According to Article 12 of the Law of the People's Republic of China "On Education," Chinese language and writing are basic for schools and other educational institutions. 
Schools and other educational institutions that teach mainly representatives of small nations can teach in the language of a particular nationality or languages of a particular region.

Hong Kong: status features

Hong Kong is directly subordinate to the Central People's Government (Art. 12). The Central People's Government is responsible for foreign affairs related to Hong Kong, but authorizes the SAR to conduct foreign affairs in accordance with this Law (Art. 13). The Central People's Government appoints the President of the Government and the chief officials of Hong Kong in accordance with Chapter 4 of this Law (Art. 15).

Laws passed in Hong Kong should be sent to the Standing Committee of the National People's Congress. If the Standing Committee finds that the submitted law does not comply with this Law, or affects the powers of the central authorities, it returns the law back, but has no right to correct it. Any returned law must be immediately annulled (Art. 18)

According to Article 19, Hong Kong is endowed with an independent judiciary, including the right to a final judicial decision. The Hong Kong courts have jurisdiction over all cases in the Region. Hong Kong courts do not have jurisdiction over cases related to foreign security and foreign affairs issues. The courts of the Region should receive a certificate from the President of the Government for each case when the court faces issues of external security and foreign affairs when making its decision. The specified certificate is mandatory for vessels. Before issuing such a certificate, the President of the Government must receive a corresponding document from the Central Government.

According to Article 24, residents of special administrative regions include permanent residents and non-permanent residents.

Permanent residents of the Hong Kong SAR are:

1. Chinese citizens born in Hong Kong before or after the formation of the SAR.

2. Chinese citizens who have been continuously residing in Hong Kong for 7 years before or after the establishment of the SAR.

3. Chinese citizens born outside Hong Kong, but who are relatives of the citizens specified in the first two paragraphs.

4. Non-Chinese citizens who have entered Hong Kong on the basis of relevant documents, have been continuously residing in Hong Kong for at least 7 years and consider Hong Kong a place of permanent residence before or after the establishment of the SAR.

5. Persons under the age of 21 who were born in Hong Kong to persons listed in Category 4 before or after the creation of the SAR.

6. Persons who before the creation of the SAR had a right of permanent residence in Hong Kong only.

The above-mentioned residents must have permanent identity cards, which indicate their right to permanent residence. Non-permanent residents of the SAR are persons who have Hong Kong identity cards, but do not have the right to permanent residence. 
Permanent residents - the right to vote and the right to participate in elections (Art. 26). Non-permanent and permanent residents are equal before the law (Art. 25).

According to Article 43, the Chief Executive of the Hong Kong SAR is the President of the Hong Kong Government and a representative of the Region. In accordance with this Law the President of the Government is responsible to the Central People's Government.

According to Article 44, the President of the Government is a Chinese citizen, at least 40 years old, a permanent resident of the Region, without a right to stay in any foreign country, with a permanent residence in Hong Kong for at least 20 years (for 5 years, no more than 2 terms). According to Article 45, the President of the Government must be appointed by the Central People's Government after local elections and consultations. According to Article 47, the President of the Government, upon taking office, must declare all his income to the Chief Judge of the Court of Final Appeal of the Hong Kong SAR. This declaration must be made in writing.

\section{Formation of Executive Power in Hong Kong}

According to Article 54, the Executive Council of the Hong Kong SAR should be a body to assist the President in governing. According to Article 55, the members of the Executive Council must be appointed by the President of the Government from the main officials, members of the Legislative Council and representatives of the society, i.e. the decision on their appointment or removal can be made by the President of the Government. The term of office should not be longer than the term of the President who appointed them. The members of the executive council must be Chinese citizens, permanent residents of the Region, and not have the right of residence in any foreign country.

According to Article 59, the Government of the Hong Kong SAR should consist of executive authoritative representatives of the Region. According to Article 60, the Administration Department, Finance Department, various bureaus, offices and commissions should be established in the Hong Kong SAR Government. According to Article 63, the Department of Legality ensures the work of the courts, excluding any interference in their activities. According to Article 64, the Government must comply with the laws and be accountable to the Legislative Council of the Region. It must comply with the laws passed by the Council, it must regularly inform the Council, respond to requests from Council members, and receive the approval of the Council for Tax and Public Expenditures.

\section{Formation of Legislative Power in Hong Kong}

According to Article 66, the Legislative Council should be the law-making body in the Region. According to Article 67, the Legislative Council should be formed of Chinese citizens, permanent residents of the Region, without the right to reside in 
another country. However, permanent residents of the region, non-Chinese citizens, or those who have a right of residence in another country can also be elected to the Legislative Council, provided that their number does not exceed $20 \%$ of the total composition of the Council.

According to Article 68, the Legislative Council must be elected. The method for forming the council should be determined on the basis of the Region actual situation, according to the principle of gradual and normal development based on universal suffrage (a special method for the formation of the Legislative Council and the procedures for voting and nominating candidates is set out in Annex 2 of this Law).

According to Article 71, the Chairman of the Legislative Council must be elected from among the members of the Council - a Chinese citizen, a permanent resident of the Region, at least 40 years old, without the right of residence in another country, who has lived in the Region for at least 20 years continuously.

According to Article 80, the courts of the SAR exercise judicial power in the Region. According to Article 81, the following courts are approved in Hong Kong: the Court of Final Appeal, the Supreme Court, District Courts, Magistrates' Courts and other special courts. The Supreme Court includes the Court of Appeal and the Court of First Instance. The legal practice previously applied in Hong Kong remains, except for the consequences associated with the establishment of the Hong Kong Court of Final Appeal.

\section{Advantages and Necessity of Establishing the Status of a Special Administrative Region}

The practice proved to be very effective in maintaining Hong Kong and Macao for more than 20 years of long-term stability and prosperity. The reason lies in the fact that the "One Country, Two Systems" framework can reach a consensus in seeking common ground while preserving differences. Recognizing the development of capitalism under the premise of one country is a key to political stability, economic prosperity and common good. It protects the fundamental interests of the PRC as well as its people, the unity of national sovereignty by legally stating that the People's Republic of China under the leadership of the Communist Party of China implements a socialist system dominated by public ownership in the mainland, and a capitalist system of private ownership in the two SARs of Hong Kong and Macau. Hong Kong successfully resisted the impact of the Asian financial crisis, the SARS epidemic and the international financial crisis. It has a status as an international financial, shipping, and trading center, and is continuously ranked by many international institutions as the world's freest and most competitive economy.

From the political perspective, this framework refers to a peaceful way to protect national sovereignty and territorial integrity. The "One Country, Two Systems" strategy created a precedent for the peaceful settlement of international disputes. In case 
of China, it guarantees its territorial integrity and sovereignty, reduces grounds for social unrest before and after the return of Hong Kong and Macao, and facilitates a smooth transition after the return.

Within this framework, the Basic Law protects a right of two different social systems to develop together under unified national sovereignty. It avoids chaos and turmoil due to different ideologies.

From the economic perspective, the framework contributes to national development in general. Since the return of Hong Kong and Macau, the central government supported the development of SARs by signing the "Closer Economic Partnership Arrangement," supporting Hong Kong and Macau in responding to the Asian and international financial crises, and supported Hong Kong in maintaining its status as an international financial, shipping, and trade center. Statistics proved that with the strong support, the two SARs continued to develop steadily and prosperously. In 2018, Hong Kong's GDP was 285 million HK dollars, an increase of 108\% over 1997. The growth rate of major economic indicators over the same period was among the highest among developed economies. At present, with the construction of the Guangdong-Hong Kong-Macao Greater Bay Area, the two SARs will be more closely linked with the development of the mainland.

In terms of culture, this framework allows two SARs to acquire characteristics of both Chinese and Western civilizations, and at the same time maintain a different political system from the mainland. Thus, it is necessary for the two cities to benefit from the cultural and systematic advantages of both types in order to establish their own model of development within the framework "One Country, Two Systems."

\section{Problems Revealed in the Process of Development}

The above-analyzed material shows that the "One Country, Two Systems" framework has been successfully applied in Hong Kong during the past 20 years. At the same time new challenges appear. The recent series of violent attacks in Hong Kong that undermined its economic development and social stability revealed its shortcomings after more than 20 years of operation.

"One Country, Two Systems" implies a country with two systems, but there is no complete governance power. According to Foucault, the power applies itself to immediate everyday life which categorizes the individuals, identifies their individuality and identity, imposes a law of truth on them which they must obey, and which others have to recognize in them. It is a form of power which makes individuals subjects. ${ }^{8}$ But Hong Kong still sticks to a traditional way of governing, it is different in many aspects (identity, institutionalization, legislation) from the central government power; from this perspective it is separated from it.

8 Michel Foucault, The Subject and Power, 8(4) Crit. Inq. 777 (1982). 
To be precise, the framework operates without full governance of SARs, which means that unified administration of the region by the central government is lacking in Hong Kong and Macau. Consequently, it is impossible to achieve complete control over judicial, education, public security systems, over media and publication, as well as government officials. The exercise of power comprises

a total structure of actions brought to bear upon possible actions; it incites, it induces, it seduces, it makes easier or more difficult; in the extreme it constrains or forbids absolutely. ${ }^{9}$

Among all these, violence must have been its primitive form, its permanent secret and its last resource, according to Foucault. The effective governing is unattainable because of the lack of the above-mentioned mechanisms.

In other words, the hegemony, with economic and political leadership, as well as cultural, moral and ideological dominance hinders effective development of the Hong Kong SAR. In Hong Kong it results in a controversial attitude to the national ideology and identity under the leadership of CPC. It is more common among young people who are closely connected to the western culture due to globalization.

\section{Conclusion}

To conclude, the framework of "One Country, Two Systems" can considerably protect the fundamental interests of the society on order to achieve peace and compromise. The use of this power model ensured a long period of political and economic stability and successful development in many directions. However, the current contradictions prove the need to introduce changes and keep a clear-cut balance between national and regional views on Hong Kong long-term development.

Any system has its limitations and validity period and must be adjusted to the changing external environment. Now, after 20 years of the "One Country, Two Systems" model implementation, its disadvantages are becoming more evident. This model needs transformation to avoid contradictions and unrest.

\section{Acknowledgements}

This article was prepared in the framework of the work on the grant of the President of the Russian Federation for young scientists No. MK-6113.2021.2 on the topic "The State Structure of Russia and China: Comparative Legal Research."

\footnotetext{
9 Michel Foucault, The Subject and Power, 8(4) Crit. Inq. 777 (1982).
} 


\section{References}

Creswell J.W. \& Plano Clark V.L. Designing and Conducting Mixed Methods Research ( $2^{\text {nd }}$ ed. 2011).

Faure M. \& Hartlief T. Economic Analysis in The Impact of Social Security Law on Tort Law 222 (Ulrich Magnus ed., 2003).

Firth M. et al. Friend or Foe? The Role of State and Mutual Fund Ownership in the Split Share Structure Reform in China, 45(3) J. Fin. Quant. Anal. 685 (2010). https://doi.org/10. 1017/s0022109010000190

Foucault M. The Subject and Power, 8(4) Crit. Inq. 777 (1982).

Luney P.R., Jr. Traditions and Foreign Influences: Systems of Law in China an, 52(2) L. Contemp. Probl. 129 (1989). https://doi.org/10.2307/1191940

Postiglione G.A. Education and Social Change in China: Inequality in a Market Economy (2006). https://doi.org/10.4324/9781315704937

\section{Information about the authors}

Nina Symaniuk (Yekaterinburg, Russia) - Associate Professor, Department of Theory, Methodology and Legal Support of State and Municipal Management, Graduated School of Economics and Management, Ural Federal University (19 Mira St., Yekaterinburg, 620002, Russia; e-mail: n.v.symaniuk@urfu.ru).

Olga Tomberg (Yekaterinburg, Russia) - Professor, Department of Linguistics and Professional Communication in Foreign Languages, Ural Institute of Humanities, Ural Federal University (19 Mira St., Yekaterinburg, 620002, Russia; e-mail: o.v.tomberg @urfu.ru).

Xiaowen Zhang (Shanghai, China) - PhD Student, Shanghai University (Shangda Rd., BaoShan District, Shanghai, 200444, China, e-mail: haruka0127@126.com). 